\title{
Geological context and micromammal fauna characterisation from the karstic infilling of La Pedrera (Albaida, Valencia, E Spain)
}

\author{
Ana FAGOAGA ${ }^{1,2^{*}}$, Francisco Javier MOLINA3, Vicente D. CRESPO ${ }^{1,2}$, César LAPLANA ${ }^{4}$, \\ Rafael MARQUINA ${ }^{1,2}$ \& Francisco J. RUIZ-SÁNCHEZ $Z^{1,2,5}$
}

${ }^{1}$ Grup d'Investigació en Paleontologia de Vertebrats Cenozoics. Departament de Botànica i Geologia, Universitat de València, Dr. Moliner, 50, 46100, Valencia, Spain; ana.fagoaga@uv.es; vicente.crespo@uv.es; rafael.marquina@uv.es; francisco.ruiz@uv.es

${ }^{2}$ Museu Valencià d'Història Natural, L’Hort de Feliu, P.O. Box 8460, Alginet, 46018, Valencia, Spain

${ }^{3}$ Universidad de Alicante, San Vicente del Raspeig, s/n, 03690, Alicante, Spain; jammoninte@gmail.com

${ }^{4}$ Museo Arqueológico Regional de la Comunidad de Madrid. Plaza de las Bernardas s/n. 28801 Alcalá de Henares, Madrid; cesar.laplana@gmail.com

${ }^{5}$ INCYT-UPSE, Universidad Estatal Península de Santa Elena, 7047, Santa Elena, Ecuador

* Corresponding author

Fagoaga, A., Molina, F.J., Crespo, V.D., Laplana, C., Marquina, R. \& Ruiz-Sánchez, F.J. 2017. Geological context and micromammal fauna characterisation from the karstic infilling of La Pedrera (Albaida, Valencia, E Spain). [Contexto geológico y caracterización de la fauna de micromamíferos del relleno kárstico de La Pedrera (Albaida, Valencia, E España)]. Spanish Journal of Palaeontology, 32 (2), 241-260.

\section{ABSTRACT}

La Pedrera is a new palaeontological site located south of the province of Valencia, between the Betic and Iberian Ranges, in a cavity filled with sediments inside a tufa formation. Roughly 260 fossil remains, corresponding to 14 taxa, have been recovered and studied from Unit III. Six rodents (Microtus sp., M. sp. gr. M. (Terricola) duodecimcostatuslusitanicus, Microtus sp. gr. M. brecciensis-cabrerae, Arvicola sapidus, Eliomys quercinus, and Apodemus sp. gr. sylvaticusflavicollis), one lagomorph (Oryctolagus cf. cuniculus), three insectivores (Soricinae indet., Crocidura sp., and Talpa cf. europaea) and four bats (Myotis blythii, Rhinolophus cf. ferrumequinum, Myotis bechsteinii, and Rhinolophus euryale) have been identified. The relative chronology obtained by means of the identified species and geological information suggests that this part of the cavity was filled with sediments during the Late Pleistocene or the beginnings of the Holocene. Furthermore, Mutual Ecogeographic Range method and

\section{RESUMEN}

La Pedrera es un yacimiento paleontológico localizado en el sur de la provincia de Valencia, entre las Cordilleras Bética e Ibérica, en una cavidad rellena con sedimentos dentro de una formación tobácea. Se han estudiado cerca de 260 fósiles, correspondientes a 14 taxones, procedentes de la Unidad III. Han sido identificados seis roedores (Microtus sp., M. sp. gr. M. (Terricola) duodecimcostatus-lusitanicus, M. sp. cf. M. brecciensis-cabrerae, Arvicola sapidus, Eliomys quercinus y Apodemus sp. gr. sylvaticus-flavicollis), un lagomorfo (Oryctolagus cf. cuniculus), tres insectívoros (Soricinae indet., Crocidura sp. y Talpa cf. europaea) y cuatro murciélagos (Myotis blythii, Rhinolophus cf. ferrumequinum, Myotis bechsteinii y Rhinolophus euryale). La cronología relativa obtenida a través de las especies identificadas y la información geológica apuntan a un relleno de esta parte de la cavidad durante el Pleistoceno Superior o inicios del Holoceno. El método Mutual Ecogeographic Range (Rango 
Habitat Weighting method show colder and wetter conditions than in Albaida (Valencia, Spain) nowadays.

Keywords: Biochronology, palaeoenvironment, palaeoclimate, Mutual Ecogeographic Range method, Habitat Weighting method.
Ecogeográfico Mutuo) y el método de la Ponderación de los Hábitats muestran condiciones más frías y húmedas que las que se dan en Albaida (Valencia, España) en la actualidad.

Palabras Clave: Biocronología, paleoambiente, paleoclima, Rango Ecogeográfio Mutuo, Método de la Ponderación de los Hábitats.

\section{INTRODUCTION}

The Late Pleistocene (ca. 128-11.2 ka) is a period of time characterized by several climatic, faunistic and cultural changes (Heinrich, 1988; Bond et al., 1997; Cacho et al., 1999; Sánchez-Goñi \& d'Errico, 2005, Cuenca-Bescós et al., 2010). The climatic history of the Late Pleistocene has been inferred from a wide range of evidences (deep-sea and lake sediments, ice cores, glacial landforms, coral reefs, ancient groundwater, cave records, overconsolidated sediments, loess deposits, fossil pollen, and relative sea-level reconstructions (Marshall, 2009 and references therein)). Especially, results derived from several oceanographic campaigns of the International Marine Global Change Study (IMAGES), around the Iberian margin, have contributed hugely to the knowledge of the response of the Iberian Peninsula ecosystems to climate changes in the last 140.000 years (Sánchez-Goñi \& d'Errico, 2005).

Micromammals, especially rodents, constitute a valuable tool for biostratigraphy due to their cosmopolitan distribution and their high rates of evolution (Chaline, 1972; van der Meulen, 1973; Agustí, 1986; Fejfar \& Heinrich, 1989; Fejfar et al., 1998; Maul \& Markova, 2007; Cuenca-Bescós et al., 2010). Small mammals also represent a valuable proxy for the reconstruction of past environments (Andrews, 1990) as they are closely linked to environmental variations and present high ecological exigencies (Delany, 1976; Stoddart, 1979). Therefore, such species are a good instrument to study and reconstruct the history of the different moments represented on palaeontological and archaeological sites (Chaline, 1988; Andrews, 1999; Cuenca-Bescós et al., 2009).

In this work, we want to introduce La Pedrera site, a previously unknown locality discovered in 2002 by local people who immediately contacted with the competent authorities who prospected the area and catalogued the site. Its name comes from the traditional stone extraction areas near the site, exploited since Middle Ages to modern times. This work analyzes this site for the first time, presenting the geological context of the karstic infilling in the tufa formation as well as the information derived from systematic palaeontology, biochronology, palaeoenvironmental and palaeoclimatic reconstruction through the study of the micromammal content of Unit III of this site.

\section{GEOLOGICAL SETTING}

The studied area is located in the synclinal basin of Vall d'Albaida (Valencia, Spain), between the Betic and Iberian Ranges, south of the province of Valencia. This valley is filled with Neogene limestone and marls, and is limited to the north by the Cretaceous anticlines of Sierra Grossa, La Solana and Macizo de Marxuquera, and to the south by those of Benicadell, La Filosa and La Cuta (Fig. 1).

During the Pleistocene, several tufa formations and hydromorphic soils were deposited in the basin (Estrela et al., 1993; García et al., 1979). La Pedrera site is located in one of these formations, between the city centre of Albaida and the base of Sierra de Benicadell. That formation has been cited in several scientific publications (Pulido, 1979; Vázquez-Navarro et al., 2014, among others) but it has not been extensively studied. It was formed during an interstadial period (González Martín \& Fidalgo, 2015), in a flat geomorphologic context, over the limestone and marls of Serravallian (middle Miocene) age (Fig. 2). Carbonated water came from the karstic surge located on the headwaters of the Albaida River. Tufa formation spreads over $25 \mathrm{ha}$, with a length of $1.5 \mathrm{~km}$ from the distal to the proximal part of the river, and a maximum thickness of $15 \mathrm{~m}$ (Figs. 2a-2b). It presents a flat surface until its distal part where several gradient progradation fronts appear with lots of cavities.

The age of the tufa building can be inferred from the geomorphological evolution of the drainage basin of Albaida River. Geomorphological studies points to the preservation of three levels of alluvial terraces dated as the Pleistocene (Estrela et al., 1993; Carmona et al., 1993; García et al., 1979). The lower terrace, originated during Holocene (García et al., 1979), is located at $+10 \mathrm{~m}$ and over Neogene marls. The middle terrace at $+20 \mathrm{~m}$ alternate with high frequency hydromorphic soils, red soils and tufa formations, pointing to periods of morphogenetic stability 


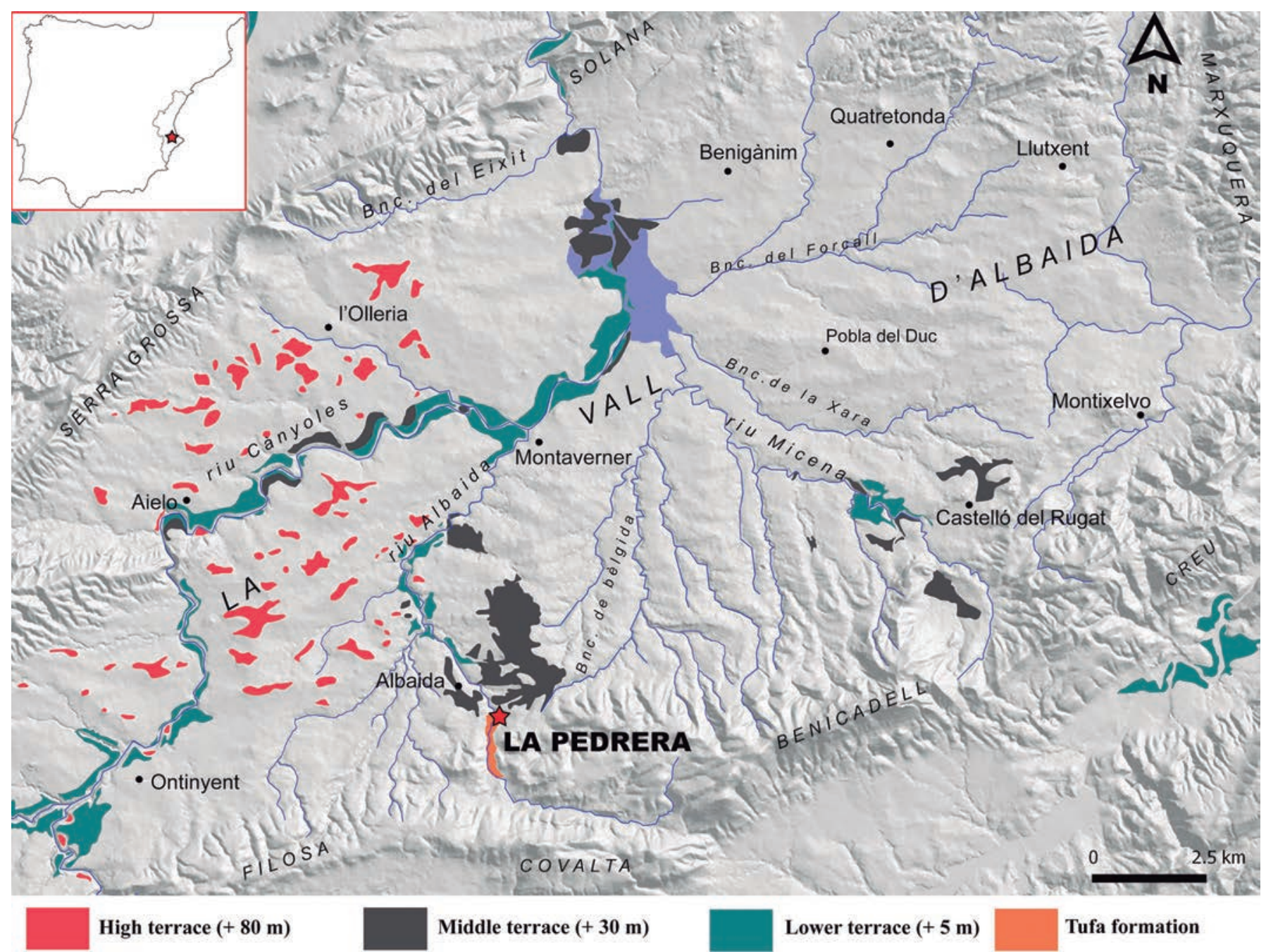

Figure 1. Quaternary set of terraces associated to Canyoles and Albaida rivers with location of the palaeontological site of La Pedrera (Vall d'Albaida, Valencia, Spain).

with lacustrine environments. Comparing with other fluvial basins, the middle terrace ranges from the final moments of the Middle Pleistocene and the beginnings of the Late Pleistocene. Then, another level of terrace, formed by detrital deposits, which is the highest one, documented at $+50 \mathrm{~m}$.

According to the data cited above, the tufa formation of Albaida could be morphologically placed between the upper and the middle terraces. The distal part of the building remains nowadays $30 \mathrm{~m}$ above the actual river. The middle terrace can be observed, connected to the distal part of the building, $20 \mathrm{~m}$ over the riverbed.

The successive fills of the Albaida River eroded and partially karstified the tufa building, forming new cavities and enlarging the older ones. Some of the cavities began to fill with external sediment input, consisting on sand, clay and rounded cobbles, and in the case of La Pedrera with macro and micromammal bones, charcoal fragments and snail shells among other remains as well.
The stratigraphic sequence result of the infill process, is composed by four sedimentary levels, from the bottom to the top (Fig. 2c):

- Unit IV (unknown thickness): Marl-sandy sediment with rounded stones of $1-5 \mathrm{~cm}$ and tufa fragments. Highly carbonated matrix.

- Unit III $(130 \mathrm{~cm})$ : Marl-sandy sediment with less carbonate. Percentage of clay rises progressively from the bottom to the top.

- Unit II $(25 \mathrm{~cm})$ : Carbonated crust of $15 \mathrm{~cm}$.

- Unit I (40 cm): Red decantation clays with abundant oncolites between $0.5-1 \mathrm{~cm}$.

In general, it can be observed that the beginning of the sedimentary infill is carbonated (IV) (Fig. 2c). Afterwards, the clay content of the sediment increases, as it acquires a more reddish hue (III). A carbonated crust was formed at the top of that level which seals the lower levels (II). Overall, the last unit completely fills the cavity, being 

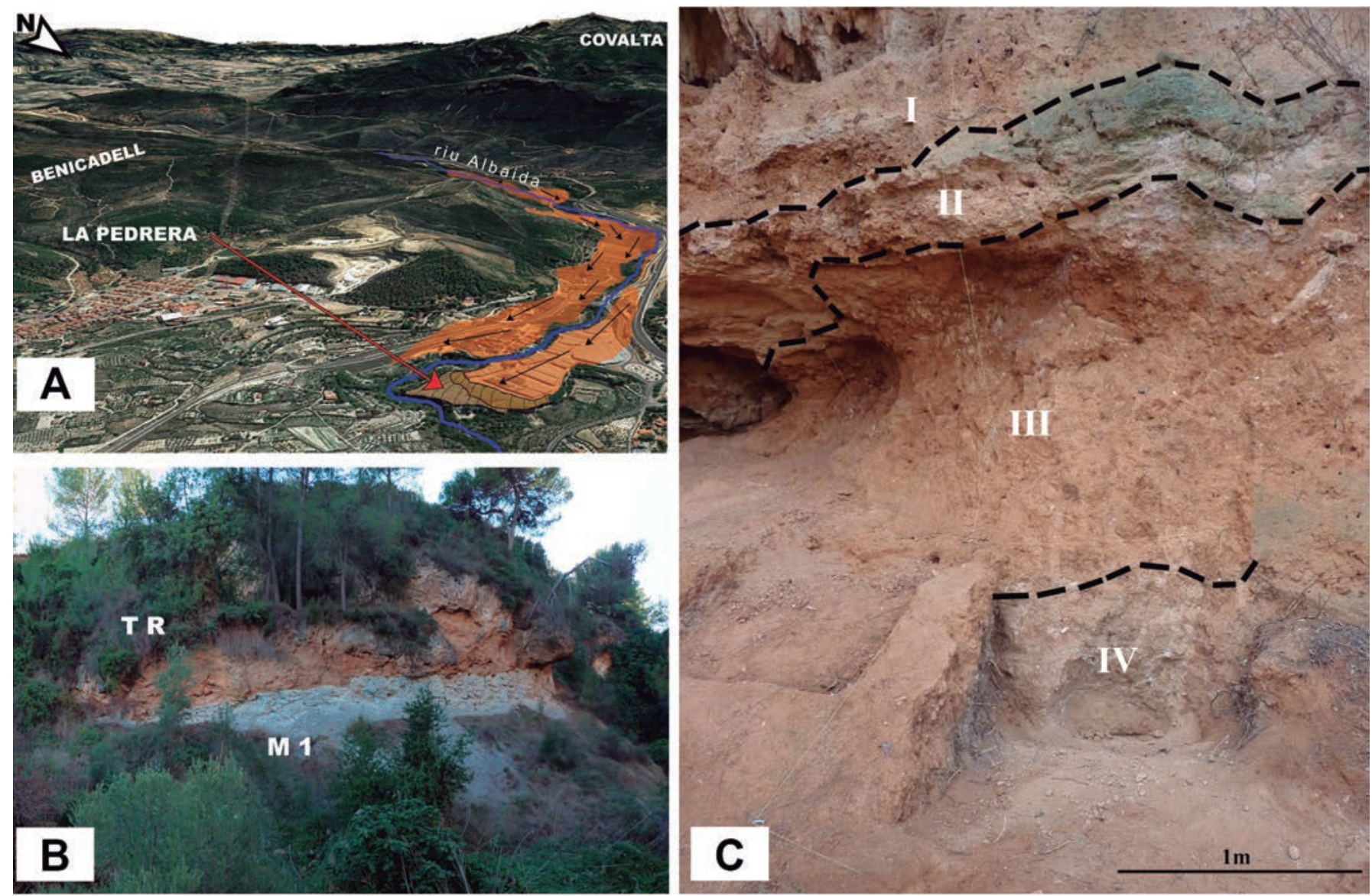

Figure 2. a) Detail of the palaeontological site of La Pedrera (Vall d'Albaida, Valencia, Spain). b) Tufa formation of La Pedrera (Vall d'Albaida, Valencia). M1: Miocene (Serravallian); TR: Travertine. c) Stratigraphic units described at the palaeontological site of La Pedrera (Vall d'Albaida, Valencia).

this unit, composed by clays and oncolites that points to its ponding (I). During the field campaign abundant macromammal remains were found in Units IV and III. These remains will be studied and published in the near future. Micromammal remains are present along the whole sequence.

\section{MATERIALS AND METHODS}

Approximately 260 small mammal remains have been studied and described in this paper. All of them were recovered from Unit III of La Pedrera karstic infilling. They are temporarily stored at the Universitat de València until their final deposit at the Isurus Paleontological Museum in Alcoi (Alicante). Samples were classified at the Department of Geology (Universitat de València), using a Leica MS5 binocular microscope. Measurements were taken (in mm) on a Leica MZ75 binocular microscope, by means of displacement of a mechanical stage, connected to a Sony Magnescale measuring equipment. Images were taken with a scanning electron microscope at the Central Support Facility for Experimental Research (SCSIE) of the University of Valencia.

The anatomical nomenclature and measurement methods follow van der Meulen (1973), Rabeder (1981) and Jeannet (2000) for arvicolines, van der Weerd (1976) for murids, Daams (1981) for glirids, Reumer (1984) for soricids, Sevilla (1988) and Fracasso et al. (2011) for bats, and ultimately Furió (2007) for talpids. The taxonomic classification follows the one given by Wilson \& Reeder (2005).

The abbreviations used throughout the text are: D: deciduous; P: upper premolar; p: lower premolar; M: upper molar; m: lower molar; MAT: Mean annual temperature; MAP: Mean annual precipitation; AW: anterior width; BL: labial length; L: Length; LL: Lingual length; PE: Posterior emargination; TAW: Talonid width; TRW: Trigonid Width; W: Width; ACC: Anteroconid Complex; T: triangle; $\mathbf{t}$ : tubercle.

The remains have been counted (NISP) and grouped using the minimum number individuals (MNI) by counting the most highly represented diagnostic element, taking into account laterality. 
To reconstruct the palaeoenvironment we use the Habitat Weighting method developed by Whittaker (1948), Rowe (1956) and Gauch (1989), using the MNI calculated for the different taxa. This procedure defines a value, ranging from 0 to 1 , for each of the species in every habitat where it is possible to find it. According to Cuenca-Bescós et al. (2005), Blain et al. (2008) and López-García et al. (2010), the habitats used are: Open dry (OD), meadows under seasonal climate change; Open humid $(\mathrm{OH})$, evergreen meadows with dense pastures and suitable topsoil; Woodland (W), mature forest including woodland margins and forest patches, with moderate ground cover; Rocky (R), areas with a suitable rocky or stone substratum; Water (Wa), areas along streams, lakes and ponds. The score for the species identified in each habitat is shown in Table 1.

Table 1. Minimum number of individuals (MNI) and habitat preferences (OD: Open dry; OH: Open humid; Wo: Woodland; R: Rocky; Wa: Water) of the species determined from La Pedrera site (Unit III).

\begin{tabular}{|c|c|c|c|c|c|c|}
\hline & MNI & OD & $\mathrm{OH}$ & Wo & $\mathrm{R}$ & $\mathrm{Wa}$ \\
\hline Microtus sp. & 1 & & & & & \\
\hline $\begin{array}{l}\text { M. sp. gr. } M . \\
\text { brecciensis-cabrerae }\end{array}$ & 1 & & & & & \\
\hline $\begin{array}{l}\text { M. (Terricola) sp. gr. } \\
\text { M. duodecimcostatus- } \\
\text { lusitanicus }\end{array}$ & 3 & & 0.5 & 0.5 & & \\
\hline Arvicola sapidus & 1 & & & & & 1 \\
\hline Eliomys quercinus & 3 & & & 0.5 & 0.5 & \\
\hline $\begin{array}{l}\text { Apodemus sp. gr. } \\
\text { sylvaticus-flavicollis }\end{array}$ & 8 & & & 1 & & \\
\hline $\begin{array}{l}\text { Oryctolagus cf. } \\
\text { cuniculus }\end{array}$ & 16 & 0.8 & 0.2 & & & \\
\hline Crocidura sp. & 2 & 0.5 & & 0.5 & & \\
\hline Talpa cf. europaea & 1 & & 0.5 & 0.5 & & \\
\hline Soricinae indet. & 1 & & & & & \\
\hline Myotis blythii & 2 & 0.25 & 0.25 & & 0.5 & \\
\hline $\begin{array}{l}\text { Rhinolophus cf. } \\
\text { ferrumequinum }\end{array}$ & 1 & & & 0.8 & 0.2 & \\
\hline Myotis bechsteinii & 1 & & & 0.9 & 0.1 & \\
\hline Rhinolophus euryale & 1 & & & 0.5 & 0.5 & \\
\hline
\end{tabular}

Taxonomic composition of the assemblage allows us to evaluate the prevailing climatic conditions at the time of the formation of this Unit (Hernández-Fernández \& PeláezCampomanes, 2005). As an approach to assess the climatic conditions, we have used the Mutual Ecogeographic Range method (MER) (Blain et al., 2009, 2016), which identifies the geographic regions where all the species of the assemblage live nowadays and extrapolate the current mean values for the climatic parameters to our
Unit. Parameters estimated are mean annual temperature (MAT) and mean annual precipitation (MAP). Species distribution was extracted from "El Atlas y Libro Rojo de los Mamíferos terrestres de España" (Palomo et al., 2007) and climatic information from World Clim 1.4 (30 arcseconds resolution grid) (Hijmans et al., 2005), which were both represented on free software GIS. Ecological requirements of the different species determined in the sample have been taken into account, since the areas where some species cannot actually live were removed from the overlapping area (an artificial division without any real ecological base). The results have been compared to the conditions prevailing at the present moment in the municipality of Albaida $\left(16.1^{\circ} \mathrm{C}, 463.47 \mathrm{~mm}\right)$. Climatic parameters have been calculated as described above by using geographic information applications. Despite of being good climate markers (McCoy \& Connor, 1980), Chiroptera have been excluded from this study because of their long-distance migrations.

The use of methodologies as Habitat Weighting method and Mutual Ecogeographic Range (MER method) based on actualism, can be justified since all the species identified at the site survived until today (most of them in the same region) and are morphologically similar to their modern representatives (Blain, 2009; López-García et al., 2012). This approach will be tested in future studies using other proxies (study of isotopes in snails or teeth, among others).

\section{SYSTEMATIC PALAEONTOLOGY}

\author{
Phylum CHORDATA Bateson, 1885 \\ Class MAMMALIA Linnaeus, 1758 \\ Order EULIPOTYPHLA Waddell et al., 1999
}

Family Soricidae Fischer von Waldheim, 1817

Subfamily Crocidurinae Milne-Edwards, 1874

Genus Crocidura Wagler, 1832

Crocidura sp.

(Fig. 3a)

\author{
Material. 2 M1 (CVAI00622, CVAI00623), 1 M2 \\ (CVAI00629) (Table 2).
}

\section{Description.}

M1. The metaloph does not reach the hypocone. There is a well-developed hypoconal flange and a pronounced posterior emargination. The lingual cingulum is small. The hypocone is high and conical, and connected to the 
Table 2. Measurements, in millimetres, of the teeth of micromammals at La Pedrera. N: number of specimens measured; Min: Minimum value measured; Max: Maximum value measured; SD: standard deviation.

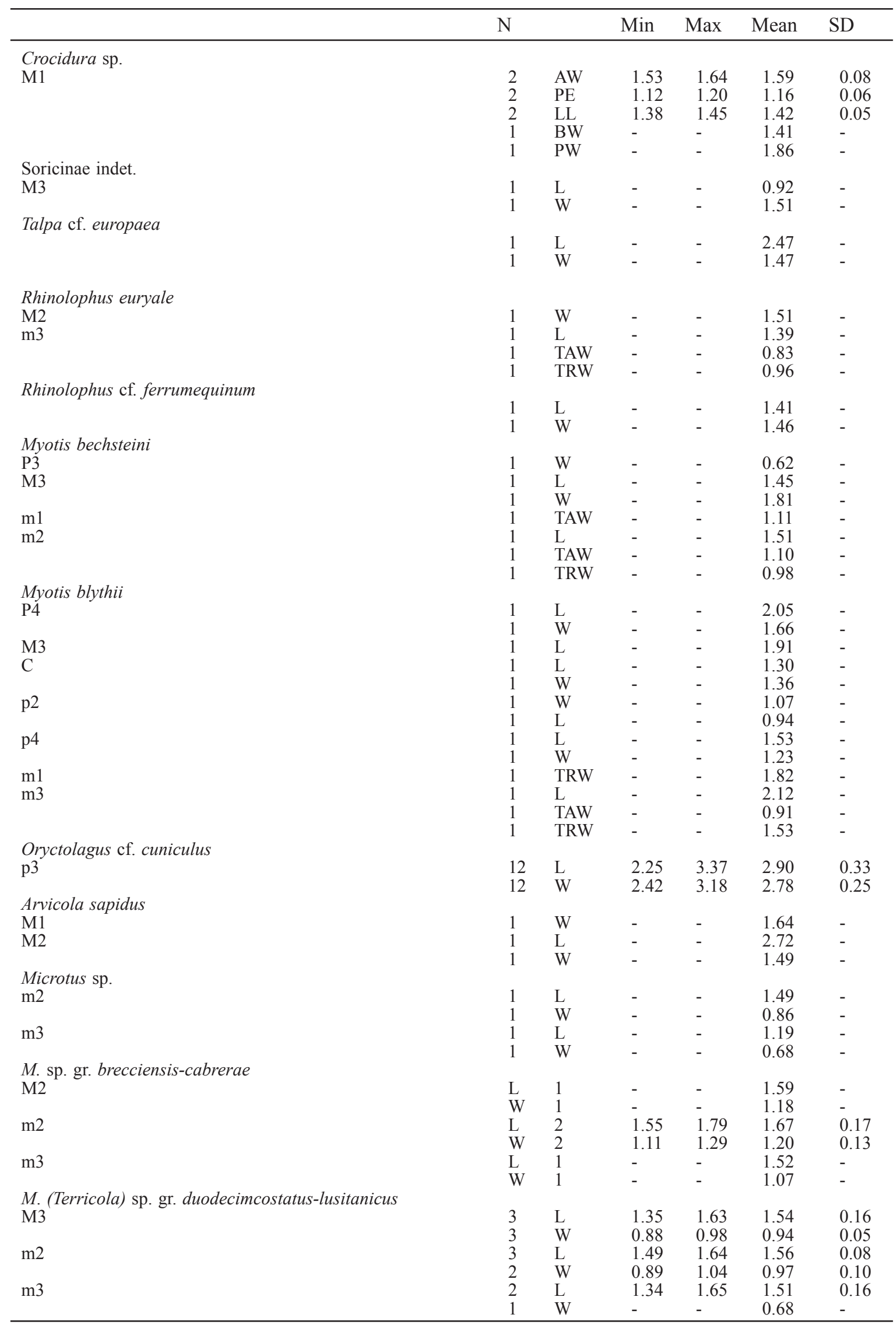




\begin{tabular}{|c|c|c|c|c|c|c|}
\hline & $\mathrm{N}$ & & Min & Max & Mean & SD \\
\hline \multicolumn{7}{|c|}{ Apodemus sp. gr. sylvaticus-flavicollis } \\
\hline \multirow[t]{2}{*}{ M1 } & 12 & $\mathrm{~L}$ & 1.79 & 2.36 & 2.06 & 0.16 \\
\hline & 13 & $\mathrm{~W}$ & 1.17 & 1.42 & 1.33 & 0.07 \\
\hline \multirow[t]{2}{*}{ M2 } & 9 & $\mathrm{~L}$ & 1.29 & 1.47 & 1.38 & 0.14 \\
\hline & 9 & $\mathrm{~W}$ & 1.19 & 1.29 & 1.25 & 0.13 \\
\hline \multirow[t]{2}{*}{ M3 } & 5 & $\mathrm{~L}$ & 0.91 & 0.99 & 0.95 & 0.03 \\
\hline & 5 & W & 0.84 & 0.94 & 0.88 & 0.04 \\
\hline \multirow[t]{2}{*}{$\mathrm{m} 1$} & 12 & $\mathrm{~L}$ & 1.82 & 1.98 & 1.89 & 0.05 \\
\hline & 13 & W & 1.09 & 1.25 & 1.14 & 0.05 \\
\hline \multirow[t]{2}{*}{$\mathrm{m} 2$} & 14 & $\mathrm{~L}$ & 1.27 & 1.37 & 1.31 & 0.03 \\
\hline & 13 & W & 1.09 & 1.26 & 1.15 & 0.04 \\
\hline \multirow[t]{2}{*}{$\mathrm{m} 3$} & 12 & $\mathrm{~L}$ & 0.95 & 1.21 & 1.06 & 0.07 \\
\hline & 12 & $\mathrm{~W}$ & 0.77 & 1.00 & 0.91 & 0.07 \\
\hline \multicolumn{7}{|c|}{ Eliomys quercinus } \\
\hline \multirow[t]{2}{*}{ D4 } & 3 & $\mathrm{~L}$ & 1.04 & 1.39 & 1.21 & 0.18 \\
\hline & 3 & W & 1.24 & 1.73 & 1.55 & 0.27 \\
\hline \multirow[t]{2}{*}{ M1,2 } & 7 & $\mathrm{~L}$ & 1.37 & 1.64 & 1.47 & 0.11 \\
\hline & 7 & $\mathrm{~W}$ & 1.76 & 2.06 & 1.87 & 0.11 \\
\hline \multirow[t]{2}{*}{$\mathrm{m} 1,2$} & 2 & $\mathrm{~L}$ & 1.21 & 1.35 & 1.28 & 0.10 \\
\hline & 2 & $\mathrm{~W}$ & 1.48 & 1.54 & 1.51 & 0.04 \\
\hline
\end{tabular}

Table 2. (Continued)

crest of the hypocone. The preprotocrista is in contact with the paracone. The parastyle and mesostyle are angulous. The mesostyle is continuous. The paracrest is the shortest crest in the ectoloph. The paramesocrest is longer than the postmesocrest. The metastyle is long. The posterior cingulum is well developed and ends down to the metastyle. The metacone and the protocone are higher than the paracone. The ectoloph is very asymmetric.

M2. A fragment of a tooth, with the metacone and part of the posterior cingulum preserved.

Remarks. This taxon is characterized in La Pedrera by the absence of pigmentation and because the upper molars are extended labio-lingually, both characters typical of the genus Crocidura (Furió, 2007). This genus is the only crocidurine found in Europe during the Pleistocene (Butler, 1998; Rofes \& Cuenca-Bescós, 2011). However, the lack of more diagnostic material prevents us from giving a more specific classification.

Subfamily Soricinae Fischer von Waldheim, 1817

Soricinae indet.

(Fig. 3b)

Material. 1 M3 (CVAI00624) (Table 2).

\section{Description.}

M3. The anterior cingulum is well developed and ends near to the parastyle. The cusp is integrated in the paracrest. The paracone is red. The protocone joins the anterior cingulum. The mesostyle is continuous. The postmesocrest is long and straight and ends in front of a well-developed and independent lingual cingulum.
Remarks. Only one tooth of red-toothed shrew has been found in the site of La Pedrera. This material is not diagnostic, but the presence of pigmented tooth allows us to classify it within the Soricinae (Furió, 2007).

Family Talpidae Fischer von Waldheim, 1817

Subfamily Talpinae Fischer von Waldheim, 1817

Genus Talpa Linnaeus, 1758

Talpa cf. europaea Linnaeus, 1758

(Fig. 3c)

Material. $1 \mathrm{~m} 1$ (CVAI00647) (Table 2).

\section{Description.}

m1. The trigonid is narrower than the talonid and both are about the same length. The paralophid is curved; the protoconid-metaconid crest is short. Thus, the trigonid valley has an U-shaped. The oblique cristid ends against the middle of the protoconid-metaconid crest. The talonid basin is wide and closed by a small cingulum; the reentrant valley is small, and closed by a small curved cingulum. The entostylid is well developed.

Remarks. Scarce material of this taxon has been found in the site of La Pedrera. The $\mathrm{m} 2$ is bigger than Talpa occidentalis Cabrera, 1907 described by van Cleef-Roders \& van den Hoek Ostende (2001), and fall inside of the variation of T. europaea described by these authors. In addition, the trigonid of the $\mathrm{m} 1$ in $T$. europaea is bigger than T. occidentalis as it occurs in our material (van Cleef-Roders \& van den Hoek Ostende, 2001). A new 
current species recently described in the south of France and North of Spain, Talpa aquitania Nicolas, MartínezVargas \& Hugot, 2016, is quite similar both in size and morphology to T. europaea, but there are hardly any data on its dental morphology, preventing us the comparison. So, the characteristics observed allow us to ascribe the material as Talpa cf. europaea.

Order CHIROPTERA Blumenbach, 1779

Family Rhinolophidae Gray, 1825

Genus Rhinolophus Lacépède, 1799

Rhinolophus euryale Blasius, 1853

(Figs. 3d-e)

Material. 1 M2 (CVAI00648), 1 m1 (CVAI00625), 1 m3 (CVA00620) (Table 2).

\section{Description.}

M2. Subrectangular tooth. The parastyle is set at a right angle with the preparacrista. The paracingulum is in contact with the parastyle. A short precingulum is present on the anterior side of the protocone. The ectoloph is symmetric. The metacone and the metastyle are broken. The paraloph, metaloph, hypocone, paraconule and metaconule are absent. The talon is developed as a rounded projection directed posteriorly, with a small basin enclosed by a well-developed cingulum. The postprotocrista is connected to the metacingulum, which is curved.

m1. Fragment of tooth, only conserves an 'open V'shaped trigonid. The paraconid is well developed. The paralophid and metalophid are angulous.

m3. Nyctalodont tooth, with a ' $V$ ' shaped paralophid. The protoconid is the highest cusp of the trigonid. The paraconid and the metaconid are aligned in occlusal view; the entoconid is displaced lingually. The hypoconulid is labially displaced respect to the entoconid. The entocristid is curved. The lingual cingulum is narrow and closes the trigonid basin. The labial cingulum connects the base of the paraconid to the hypoconulid, and it is narrower in the labial side and straight in lateral view.

Remarks. The size of this medium sized rhinolophid is similar to that of Rhinolophus hipposideros (Bechstein, 1800 ) and $R$. euryale, but the second species has a more robust dentition and a curved metacingulum as our material (Sevilla, 1988; Horáček et al., 2013).

Rhinolophus cf. ferrumequinum (Schreber, 1774) (Fig. 3f)

Material. 1 p4 (CVAI00641) (Table 2)

\section{Description.}

p4. A quadrate tooth, with a narrow cingulum surrounding it, except in the postero lingual side. This cingulum has a small protuberance in its postero lingual side.

Remarks. A big sized p4 has been found in La Pedrera site. This tooth is characterized by has a narrow cingulumand a big size, typical of this species (Sevilla, 1988). Although the scarcity of material and the lack of more diagnostic features prevent us the certainly assignation to this species.

\section{Family Vespertilionidae Gray, 1825}

Genus Myotis Kaup, 1829

\section{Myotis bechsteini (Kuhl, 1817)}

(Figs. 3g, 3i)

Material. 1 P3 (CVAI00634), 1 M3 (CVAI00649), 1 $\mathrm{m} 1$ (CVAI000632), $1 \mathrm{~m} 2$ (CVAI00645), 1 trigonid from a fragmented lower molar (CVAI00630) (Table 2).

\section{Description.}

P3. Subtriangular small tooth with a wide cingulum surrounding it, except in the anterolabial side.

M3. Subtriangular tooth. The parastyle is well developed and displays a rigth angle. The paracingulum is wide and connects to the protocone and the parastyle. The precingulum is very small. The paraloph and paraconule are well developed. The metacone is reduced. Both the metastyle and the postmetacrista are absent. The postprotocresta is short and it is not connected to the metacone. The talon is reduced to a small cingulum.

m1. Fragment of myotodont tooth, only conserves the talonid. The entocrestid is straight. The hypoconulid is lingually placed and is smaller than the entoconid. The postcrestid has a V-shaped. The cingulum is narrow.

m2. Myotodont tooth, with an open angle shaped paralophid. The protoconid is the highest cusp of the trigonid. The paraconid, the metaconid and the entoconid are aligned in occlusal view. The hypoconulid is labially displaced respect to the entoconid. The entocristid is straight. The lingual cingulum is small and closes the trigonid basin. The labial cingulum is wide and starts in the base of the paraconid, but finishes near to the hypoconulid. In lateral view this cingulum is narrow and irregular.

Remarks. It is a common middle sized Myotis, similar to Myotis nattereri (Kuhl, 1817). M.nattereri and $M$. bechsteini can be separated by the M3, because $M$. bechsteini has more angular upper molars and the M3, which is less reduced, presents a paraloph and paraconule (Sevilla, 1988). 
Myotis blythii (Tomes, 1857)

(Fig. 3h)

Material. 2 P4 (CVAI000628, CVAI00643), 1 M3 (CVAI00644), 1 c (CVAI00638), 1 p2 (CVAI00637), 1 p4 (CVAI00642), $1 \mathrm{~m} 1$ (CVAI00627), $1 \mathrm{~m} 3$ (CVAI00621) (Table 2).

\section{Description.}

P4. The principal cusp is well developed. The cingulum is narrow and surrounds the tooth except in the metastyle, which is curved and well developed. The talon is small.

M3. Broken tooth, with a posterior part very reduced. The parastyle is well developed. The paracingulum is narrow and is connected to the protocone and the base of the parastyle. The cingulum of the paraflex is well developed. The metacone is reduced to a crest. Both the metastyle and the postmetacrista are absent.

c. Subrectangular tooth, with a principal cusp. The cingulum is well developed and surrounds the tooth except in the anterior side. A small cuspule is present in posterolingual side.

p2. Rounded tooth, with a wide cingulum surrounding it. It has a small protruding in its anterior and postero lingual side.

p4. Subrectangular tooth, with only one principal cusp. The cingulum is well developed, and it is narrow in its labial side. Two cuspules are present in the anterolingual and posterolabial side.

m1. Fragment of tooth that only preserves an 'open- $V$ ' shaped trigonid. Paraconid and metaconid have a similar size. The cingulum is wide.

m3. Myotodont tooth with an ' $U$ ' shaped paralophid. The protoconid is the highest cusp of the trigonid. The paraconoid is sligthly in lingual position than the metaconid in occlusal view; the entoconid is displaced lingually. The hypoconulid is slightly labially displaced respect the entoconid. The talonid is very reduced. The entocristid is straight. The lingual cingulum is very small. The labial cingulum is wide and connects the base of the paraconid to the hypoconulid, and it is narrower in the talonid and wide and slightly irregular in lateral view.

Remarks. This species is the best-represented bat in La Pedrera. This material of La Pedrera has a big size, being in the range of Myotis myotis (Borkhausen, 1797) and the upper part of the range of Myotis blythii, but the relation between trigonid and talonid of the $\mathrm{m} 3$ is over 0.45 (specifically 0.59 ), typical feature of the second species (Sevilla, 1988).

Order LAGOMORPHA Brandt, 1855

Family Leporidae Fischer von Waldheim, 1817

\section{Oryctolagus cf. cuniculus (Linnaeus, 1758)}

(Fig. 3q)

Material. 11 I (CVAI00654 to CVAI00664), 28 i (CVAI00686 to CVAI00693, CVAI00736 to CVAI00755), 14 p3 (CVAI00667 to CVAI00670; CVAI00672 to CVAI00681), 11 p4 (CVAI00672 to CVAI00680, CVAI00684, CVAI00685), $10 \mathrm{~m} 1$ (CVAI00672 to CVAI00678, CVAI00680, CVAI00684, CVAI00685), 7 m2 (CVAI00672 to CVAI00676, CVAI0067, CVAI00684, CVAI00685), 2 m3 (CVAI00672, CVAI00673) (Table 2).

\section{Description.}

p3. The anteroconids, lingual and vestibular, are very similar in size and shape, well developed and rounded.

i1. The anterior lobes have a strong convexity and the mesial one is ledge and rounded.

Remarks. Regarding lagomorphs, upper incisors and third lower premolars are the diagnostic elements (Callou, 1997). However, third lower premolar is the dental remain with a major morphological differentiation and is usually abundant in the fossil record (De Marfà et al., 2006). In the locality of La Pedrera, it has been possible to determine $16 \mathrm{p} 3$. Anteroconids are very similar, contrary to what it's seen on hares, which are dissymmetric (Donard, 1982). However, the morphology of $\mathrm{p} 3$ tends to vary very much and that is why its biometric measures have been taken into account. The analysis that relates length versus weight shows that values fall within the values of modern Oryctolagus cuniculus (De Marfà et al., 2009). The rounded and ledge character of the upper incisors is typical of the genus Oryctolagus, instead of the low rounded shape presented on hares.

Those characters point us to identify the remains as belonging to the genus Oryctolagus. Only one species of this genus is present in the Late Pleistocene of the Iberian Peninsula, O. cuniculus. In the absence of more diagnostic elements, we ascribe the remains to Oryctolagus cf. cuniculus.

Order RODENTIA Bowdich, 1821

Family Muridae Fischer von Waldheim, 1817

Subfamily Arvicolinae Gray, 1825

Genus Arvicola Lacépède, 1799

Arvicola sapidus (Miller, 1908)

(Fig. 3p)

Material. 1 M1 (CVAI00583), 1 M2 (CVAI00587) (Table 2).

Genus Oryctolagus Linnaeus, 1758 


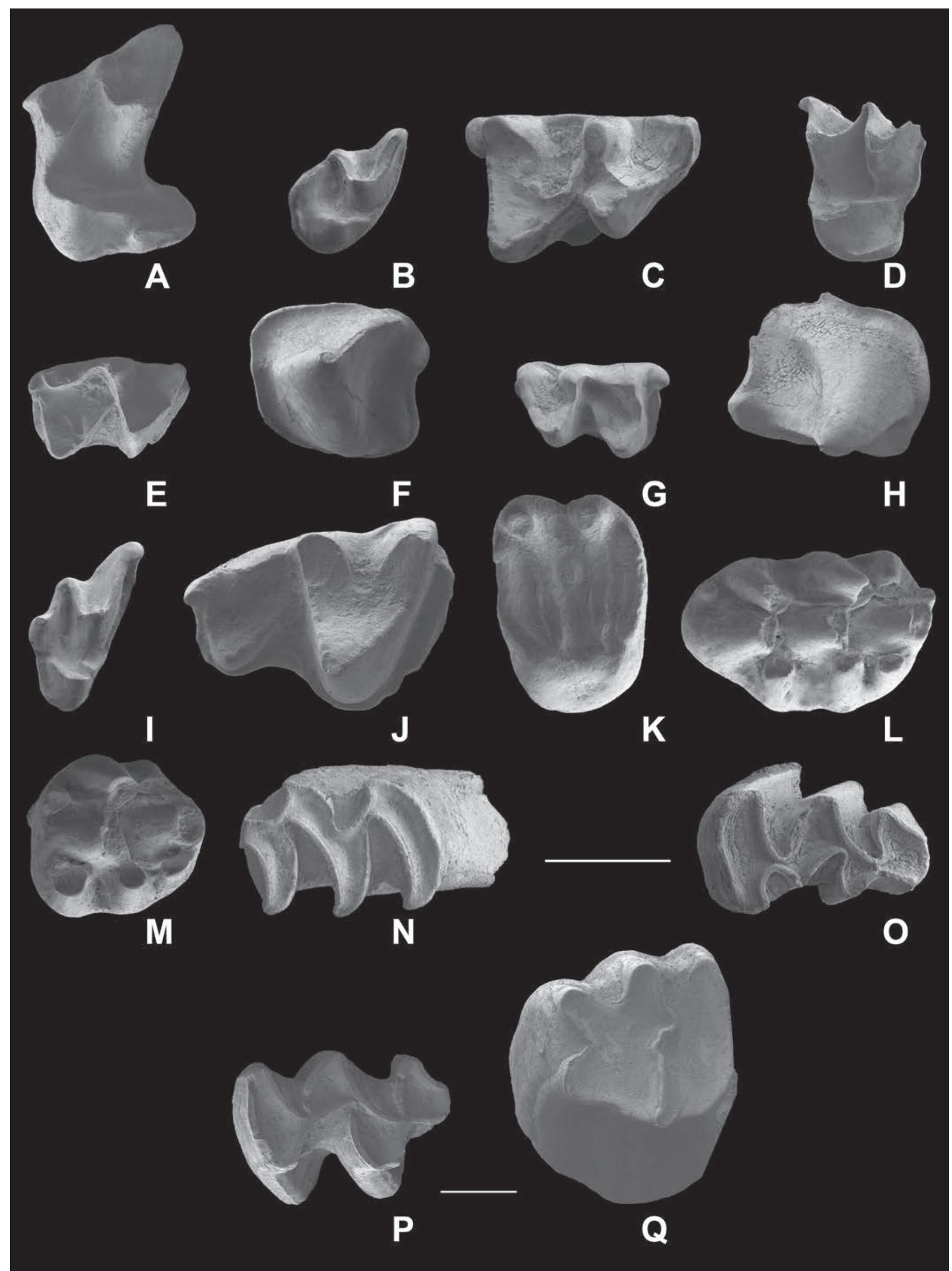




\section{Description.}

M1 and M2. The teeth are big, hypsodont, with no roots and with cement on the reentrant triangles. The enamel is differentiated, being thicker on the anterior triangles.

Remarks. Only two specimens have been recovered from this site. The big size of the molars and the thick enamel is a typical trait of the genus Arvicola. The thicker enamel in the anterior triangles (upper molars) allow us ascribe the material to Arvicola sapidus (López-Martínez, 1980).

\section{Genus Microtus von Schrank, 1798}

\section{Microtus sp.}

Material. 2 M1-2 (CVAI00586, CVAI00605), $1 \mathrm{~m} 2$ (CVAI00598) (Table 2).

\section{Description.}

M1-2. The teeth are broken. The triangles are rounded and not confluent.

m2. The triangles are rounded and not confluent.

Remarks. The specimens determined as Microtus sp. are very scarce and poorly preserved. However, the typical morphology of this genus could be seen. The triangles are rounded and not connected. In the absence of more diagnostic elements we prefer to maintain this material under open nomenclature.

Microtus sp. gr. Microtus brecciensis (Forsyth Major, 1905) cabrerae (Thomas, 1906)

(Fig. 3n)

Material. 1 M1 (CVAI00602), 1 M2 (CVAI00597), 1 M3 (CVAI00588), 3 m1 (CVAI00593, CVAI00603, CVAI00606), 2 m2 (CVAI00596, CVAI00600), 1 m3 (CVAI00610), (Table 2).

\section{Description.}

m1. The teeth are broken, hypsodont and with no roots. The reentrant angles have cement. There is a big asymmetry of the ACC. Presence of a hint of BRA4. LRA 3 and BRA 3 alternate. T4 and T5 are not confluent. The triangles are acute.

m2. The teeth are hypsodont with no roots. The reentrant angles have cement. There is a big labio-lingual asymmetry, being the lingual salients markedly longer in a lateromedial direction and more acute than the labials.

m3. The teeth are hypsodont with no roots. Reentrant angles with cement. There is a big labio-lingual asymmetry. First and second triangles are almost confluent as morphotype II from Ayarzagüena \& López-Martínez (1976).

M2. The teeth are hypsodont with no roots. The reentrant angles have cement.

M3. The teeth are hypsodont with no roots. The reentrant angles have cement.

Remarks. The marked anterioposterior compression of the molars, especially in $\mathrm{m} 1$, and the sharpness of the salient triangles are characteristic of the subgenus Iberomys (Chaline, 1972). The different morphotypes in $\mathrm{m} 1$ and $\mathrm{m} 3$ can be used to differentiate Microtus (Iberomys) brecciensis from Iberomys (Iberomys) cabrerae (Ayarzagüena \& López Martínez, 1976). However, those authors pointed the variability for those elements and noted the different proportions of each morphotype from each character in the studied populations. In the absence of more specimens with a better conservation and visible diagnostic characters, we ascribe the elements to the subgenus Iberomys. The presence of the primitive species $M$. (I.) huescarensis at La Pedrera can be excluded because the absence of confluence between triangles T4 and T5 on $\mathrm{m} 1$, which is a diagnostic feature for the species $M$. brecciensis and $M$. cabrerae. Taking into account the absence of more diagnostic elements, we identify this material as Microtus sp. gr. M. brecciensis-cabrerae.

Microtus (Terricola) Niethammer \& Krapp, 1978

Figure 3. (a-q) Some of the small mammal remains recovered from Unit III from La Pedrera (Albaida, Spain). a) CVAI00623, left M1, Crocidura sp. b) CVAI00624, right M3, Soricinae indet. c) CVAI00647, right m1, Talpa cf. europaea. d) CVAI00648, left M2, Rhinolophus euryale. e) CVAI00620, right m3, Rhinolophus euryale. f) CVAI00641, left p4, Rhinolophus cf. ferrumequinum. g) CVAI00645, left m2, Myotis bechsteini. h) CVAI00642, right p4, Myotis blythii. i) CVAI00649, right M3, Myotis bechsteini. j) CVAI00621, right m3, Myotis blythii. k) CVAI00499, left M1, Eliomys quercinus. I) CVAI00517, left M1, Apodemus sp. gr. sylvaticus-flavicollis. m) CVAI00540, left M2, Apodemus sp. gr. sylvaticus-flavicollis. n) CVAIOO610, right m3, Microtus sp. gr. Microtus brecciensis-cabrerae. o) CVAI00589, right M3, Microtus (Terricola) sp. gr. M. duodecimcostatus-lusitanicus. p) CVAI00587, left M2, Arvicola sapidus. q) CVAI00669, right p3, Oryctolagus cf. cuniculus. Scale bars $=1 \mathrm{~mm}$. 
Microtus sp. gr. Microtus (Terricola) duodecimcostatus (De Sélys-Longchamps, 1839)-lusitanicus (Gerbe, 1879). (Fig. 3o)

Material. 2 M2 (CVAI00584, CVAI00607) 5 M3 (CVAI00589 to CVAI00592, CVAI00611), 3 m2 (CVAI00594, CVAI00595, CVAI00601), 3 m3 (CVAI00609, CVAI00612, CVAI00615) (Table 2).

\section{Description.}

M2. It has no roots. The teeth are hypsodont, with cement on the reentrant triangles. The angles are not sharp.

M3. No roots. The teeth are hypsodont, with cement on the reentrant triangles. The $\mathrm{T} 2$ and $\mathrm{T} 3$ are confluent and the salient angle of the $\mathrm{T} 2$ is always shorter than previous and posterior angle.

m2. It has no roots. The teeth are hypsodont, with cement on the reentrant triangles. T3 and T4 are confluent and the angles are not sharp.

m3. It has no roots. The teeth are hypsodont, with cement on the reentrant triangles. $\mathrm{T} 3$ and $\mathrm{T} 4$ are confluent and the angles are not sharp. Big labiolingual asymmetry.

Remarks. The morphology described for the specimens, including the confluence on the cited triangles and their rounded tips, let us ascribe the elements to the subgenus Terricola. The length of the salient angle of the T2 on M3 allow us to identify the specimens as Microtus sp. gr. M. (Terricola) duodecimcostatus-lusitanicus. Giving the absence of the first lower molar, a more precise identification is no longer possible (Brunet-Lecomte et al., 1987).

\section{Subfamily Murinae Illiger, 1811}

Genus Apodemus Kaup, 1829

Apodemus sp. gr. sylvaticus (Linnaeus, 1758)-flavicollis (Melchior, 1834)

(Figs. 31-m)

Material. 15 M1 (CVAI00509 to CVAI00523), 9 M2 (CVAI00539 to CVAI00547), 5 M3 (CVAI00543b, CVAI00563 to CVAI00566), $15 \mathrm{~m} 1$ (CVAI00524 to CVAI00538), $15 \mathrm{~m} 2$ (CVAI00548 to CVAI00562), $14 \mathrm{~m} 3$ (CVAI00567 to CVAI00580) (Table 2).

\section{Description.}

M1. The t1bis is present in five of twelve specimens. The t 2 bis is present in eight of eleven specimens. There is a spur in $\mathrm{t} 1$ in only two out of fourteen specimens and almost every $\mathrm{t} 3$ have a spur, eleven out of thirteen. There is a well-developed $\mathrm{t} 7$. The $\mathrm{t} 4$ and $\mathrm{t} 7$ are variable. The $\mathrm{t} 12$ is well developed.
M2. Both $\mathrm{t} 1$ and $\mathrm{t} 3$ are big and isolated. T9 is well developed. There are four roots.

M3. The $\mathrm{t} 1$ is large and isolated. The $\mathrm{t} 3$ is absent. The $\mathrm{t} 4, \mathrm{t} 5, \mathrm{t} 6, \mathrm{t} 8$ and $\mathrm{t} 9$ are connected.

m1. The tma is well developed. The anteroconid is symetric and linked to the metaconid by a narrow crest. The labial cingulum is well developed and it has a large round $\mathrm{c} 1$ and one or two accessory cuspids. Big round or oval posterior heel shifted towards the lingual side of the molar. Two roots.

m2. The antero-labial part is large and oval. The labial cingulum is poorly developed. The posterior tubercle is big, round or oval and shift towards the lingual side. Two roots.

m3. The anterolabial cuspid is absent. Two out of fourteen have an accessory cuspid.

Remarks. Differentiation between the species of the genus Apodemus is complicated due to the similarity between the morphology and the measurements of the dentition. However, studying living populations the discrimination is possible (Michaux \& Pasquier, 1974). The relative length of the $\mathrm{m} 2$ (length/width) and the percentage of M2 with a reduced t9 (Michaux \& Pasquier, 1974; Arrizabalaga et al., 1999) are the characters, which led to differentiate between both species.

The length/width ratio of the $\mathrm{m} 2$ of the specimens from La Pedrera is high (1.14), being higher than the values of extant Apodemus sylvaticus (Linnaeus, 1766), and consistent with the values of $A$. flavicollis (Michaux \& Pasquier 1974). However, the population from La Pedrera has a well-developed $\mathrm{t} 9$ in $\mathrm{M} 2$, which is a typical morphology of A. sylvaticus. The connection between $\mathrm{t} 4$ and $\mathrm{t} 7$ in $\mathrm{M} 1$ is variable.

Giving the difficulties in discriminating both species with the material studied, we ascribe those specimens from La Pedrera site to Apodemus sp. gr. sylvaticus-flavicollis until more material of this taxon are recovered from this site.

Family Gliridae Muirhead, 1819

Genus Eliomys Wagner, 1840

Eliomys quercinus (Linnaeus, 1766)

(Fig. 3k)

Material. 3 D4 (CVAI00494, CVAI00500, CVAI00501), 4 M1 (CVAI00495, CVAI00497, CVAI00499, CVAI00503), 2 M1-2 (CVAI00498, CVAI00502), 1 M2 (CVAI00496) 5 m1-2 (CVAI00504, CVAI00506, CVAI00508) (Table 2).

\section{Description.}

D4. Only two specimens (CVAI00500, CVAI00500), have been described because of the high level of oclusal 
wear of the third (CVAI00494). The D4 has a sub-triangular outline. Protocone is the highest cusp. The anteroloph is short and connected at a low level to the paracone. The protoloph is clearly discontinuous in one specimen. No centrolophids. Metaloph is continuous. The posteroloph is low and lingually connected to the protocone.

M1. The outline is subrectangular. The anteroloph is connected basally to the paracone in three specimens and connected at medium height in another four. The paracone is the highest cusp, separated from metacone, also high. The protoloph and metaloph are continuous. The precentroloph has medium lengh in two out of four specimens and short length in another two. The postcentroloph is absent in one specimen, short in two specimens and long in another. There are three roots.

M2. The outline is trapezoidal. The anteroloph is high connected to the paracone. The paracone is the highest cusp, separated from metacone, also high. The protoloph and metaloph are continuous. There is no precentroloph and there is a short postcentroloph. There are three roots.

m1-2. All of the specimens present high level of crown wear and no one of them have been able to describe.

Remarks. Eliomys quercinus, Glis glis and Muscardinus avellanarius (Linnaeus, 1758) are the species of glirids recorded in the Iberian Peninsula during the Late Pleistocene. The morphology observed in the specimens from La Pedrera is very similar to Eliomys quercinus. The surface is clearly concave and presents well developed cusps, low number of transverse ridges and any accessory crests in the lower molars. According to Ruiz Bustos et al. (1982) and Paunesco \& Abbassi (2002), these morphologies are diagnostic features of the species $E$. quercinus.

\section{RESULTS AND DISCUSSION}

\subsection{Small mammal assemblage}

Unit III of La Pedrera site has provided a NISP of 264 that corresponds to 14 taxa and a total MNI of 42. Six rodents (Microtus sp., M. sp. gr. M. (Terricola) duodecimcostatuslusitanicus, M. sp. gr. M. brecciensis-cabrerae, Arvicola sapidus, Eliomys quercinus, and Apodemus sp. gr. sylvaticus-flavicollis), one lagomorph (Oryctolagus cf. cuniculus), three insectivores (Soricinae indet., Crocidura sp., and Talpa cf. europaea) and four bats (Myotis blythii, Rhinolophus cf. ferrumequinum, Myotis bechsteinii, and Rhinolophus euryale) have been identified.

The most represented species in the assemblage are Apodemus sp. gr. sylvaticus-flavicollis with a MNI of
8 and $O$. cf. cuniculus with an MNI of 16 . The rest of the identified species have a similar representation: Eliomys quercinus and Microtus sp. gr. M. (Terricola) duodecimcostatus-lusitanicus a MNI of 3; Crocidura sp. and Myotis blythii a MNI of 2; Microtus sp., M. sp. gr. M. brecciensis-cabrerae, Arvicola sapidus, Soricinae indet., Rhinolophus cf. ferrumequinum, Myotis bechsteinii, Rhinolopus euryale and Talpa cf. europaea poorly represented, with a MNI of 1 (Table 1).

\subsection{Biochronology}

Regarding the biochronological inferences, Microtus sp. gr. M. duodecimcostatus-lusitanicus is the most outstanding taxon for La Pedrea site. Microtus lusitanicus appeared in the Iberian Peninsula in the Late Pleistocene (Sesé, 2005; López-García et al., 2011) while Microtus duodecimcostatus has been recorded at Cueva del Agua (López-Martínez \& Ruiz-Bustos, 1977) and Cuesta de la Bajada (Santonja et al., 2014) during Middle Pleistocene. However, representatives of the subgenus Terricola are absent in the Mediterranean zone until the Late Pleistocene (Guillem, 1995; López-García et al., 2008, 2012). They have not been recorded in Middle Pleistocene sites of the same region as Bolomor and Cova Negra (Fernández Peris et al., 1994; Guillem, 1996, 2009). On the other hand, the faunal association recovered from the site is compatible with the fauna present before the entrance to the Iberian Peninsula of the genera Mus, Rattus or Suncus facilitated by human dispersion (Cucchi et al., 2005). Regarding the species M. blythii, in the Iberian Peninsula, it has been identified only at the Bronze Age levels of Cova de la Sarsa (Sevilla, 1988) and at the end of the Late Pleistocene at Cova Colomera (López-García, 2011), suggesting short chronological range for this species in this geographical realm. However, from the Early Pleistocene onwards there are numerous samples attributed to the group of species Myotis myotis-blythii in which it has not been possible to determine if only one of the two species of the group were present, or if both were present at the same time (Sevilla, 1988). For this reason, it cannot be dismissed that the presence of M. blythi in the Iberian Peninsula is much older, and this species cannot be used as a marker for the Late Pleistocene-Holocene.

All the available biochronological information, together with the chronological context derived from the geologic study, points to a Late Pleistocene to early Holocene age for the studied assemblage. The remaining species represented in the faunal association appeared in the Iberian Peninsula before the beginning of the Late Pleistocene and are present during that period (Agustí et al., 2011; Donard, 1982; Sesé \& Sevilla, 1996; CuencaBescós et al., 2010) (Fig. 4). 


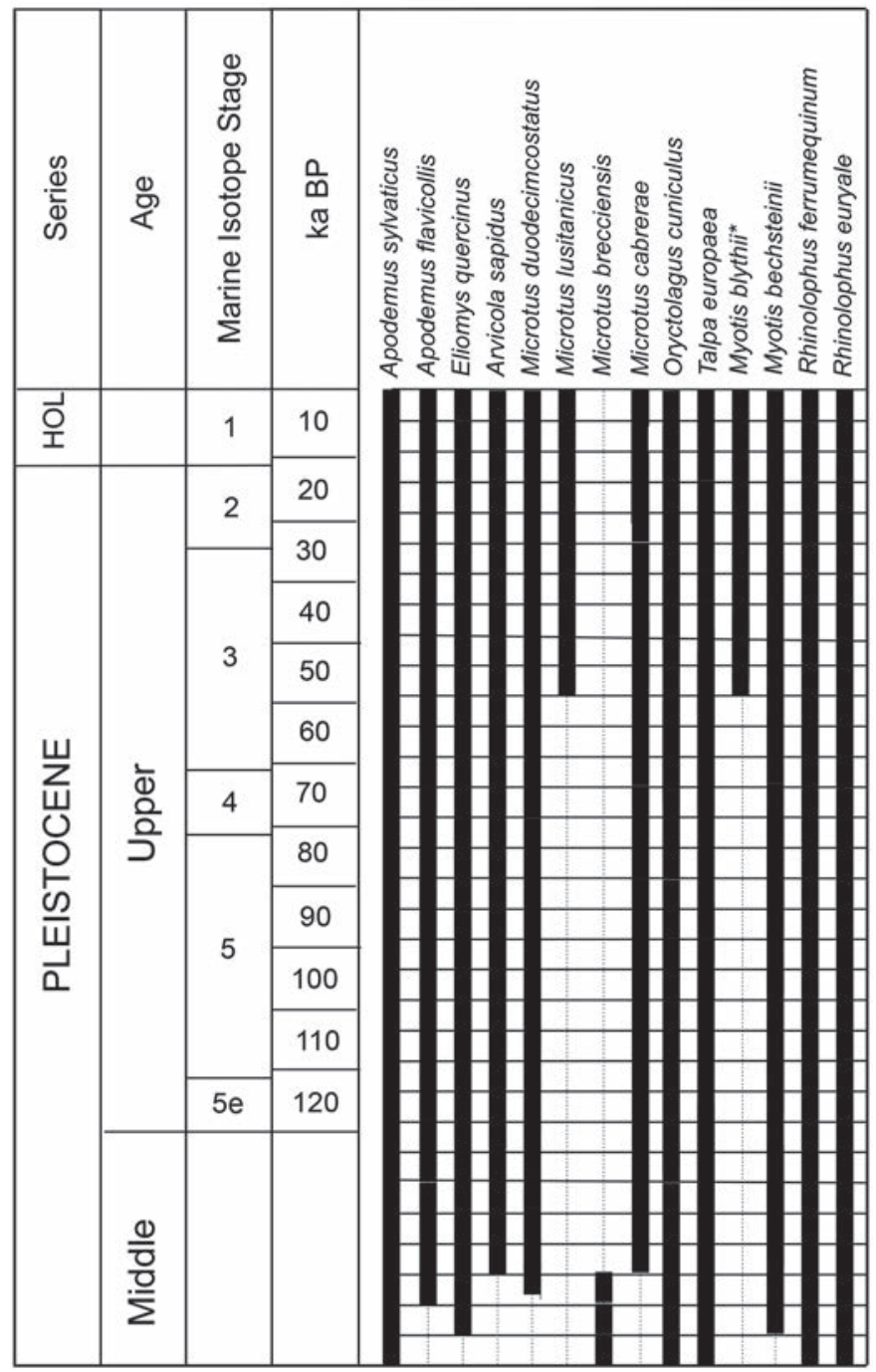

Figure 4. Biostratigraphic distribution of the species identified in Unit III from La Pedrera site. HOL: Holocene; ka: thousands of years.

\subsection{Palaeoenvironmental and palaeoclimatic reconstruction}

According to the Habitat Weighting method, the environment proposed for the surroundings of La Pedrera site consisted on a mixed habitat, where woodlands and open dry habitats would have the same representation, $38 \%$ and 37\% respectively (Fig. 5b). Moreover, it also consisted on open humid habitats (15\%) and with less importance on rocky $(8 \%)$ and water environments (2\%) (Table 1).

Furthermore, the results on the palaeoclimatic reconstruction obtained from overlapping the biogeographic distribution and climatic data show the current range of these species extending into 91 UTM squares of $100 \mathrm{~km}^{2}$, distributed between the north of Catalunya, Castilla and León, Aragón, Navarra, País Vasco, Cantabria and La Rioja regions, all of them in the northern sector of the Iberian Peninsula (Fig. 5a). The results show an MAT of 4.1 to $15.9^{\circ} \mathrm{C}($ mean $=10.7$; SD $=2.1$ ), whereas MAP ranges between 481 to $1421 \mathrm{~mm}$ $($ mean $=754.5 ; \mathrm{SD}=175.2)$.

At present, for the municipality of Albaida the climatic data, obtained using the same methodology described above, are: MAT of 14 to $16.9($ mean $=16.1 ; \mathrm{SD}=0.8)$ and a MAP between 436 and $533($ mean $=463.47 ; \mathrm{SD}=29.19)$.

The fact of not being able to count on a more accurate dating of Unit III of La Pedrera, complicates to assign a narrower age interval and therefore establishing correlations between the studied Unit and other climatic events of the Late Pleistocene or the beginning of the Holocene. Nevertheless, the palaeoenvironmental reconstruction analysis carried out with the small mammals shows that, while the unit was forming, the ecosystem was characterized by an open environment where rabbits (Oryctolagus cf. cuniculus) and mice (Apodemus sp. gr. sylvaticus-flavicollis) would dominate the open dry habitats and the woodlands respectively. Eliomys quercinus, Rhinolophus cf. ferrumequinum, Myotis bechsteinii, Rhinolophus euryale are also species strongly associated with forest conditions (Palomo et al., 2007). Humid soils would be also present according to the presence of a mole remain (Talpa cf. europaea) in the assemblage. Nowadays, the distribution of this species is restricted to the northern third of the peninsula, where the climatic conditions are colder than those that exist in the Albaida today. The identification of that taxon with mid-European requirements in La Pedrera would indicate cold conditions too. According to our data, the climatic conditions that prevailed on this ecosystem at the time of the deposit would have been colder and wetter than today.

\section{CONCLUSIONS}

The palaeontological site from La Pedrera was formed as a consequence of the infilling of the karstic system, which eroded the tufa platform due to the process of fitting of Albaida River during the Pleistocene.

Up to 260 small mammal remains have been studied, corresponding to 14 taxa and $42 \mathrm{MNI}$, belonging to the Unit III. The dating of the terrace and the assemblage described suggest a Late Pleistocene to the early Holocene age for the deposit. Palaeoenvironmental study on small mammals from Unit III shows that during its deposition temperatures were lower and rainfall higher than today. Regarding the landscape, open woodlands and open dry habitats would have been predominant in the surroundings of the site. 

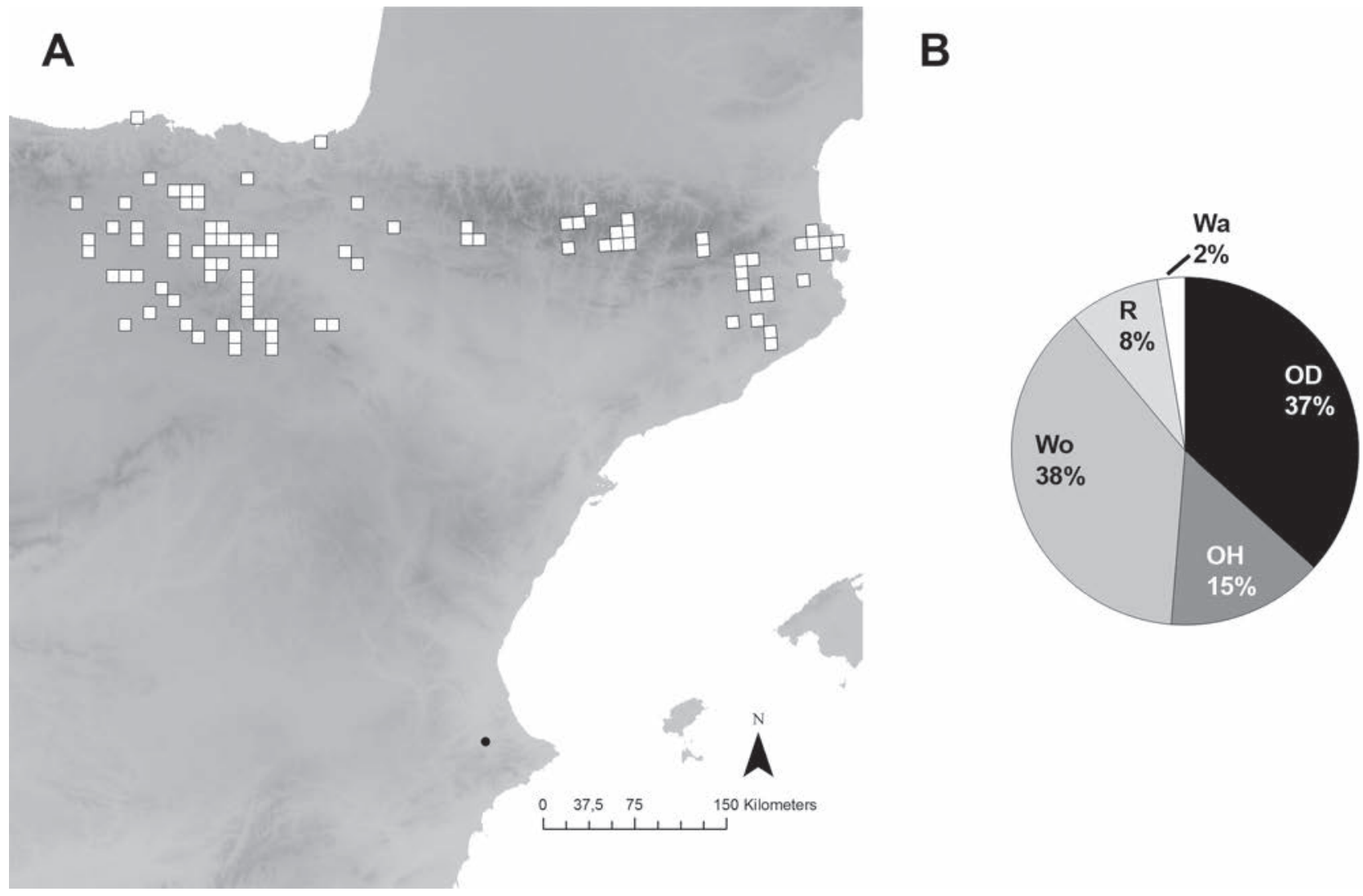

Figure 5. a) Current overlapping area of the small mammals (without bats) identified in Unit III from La Pedrera (Albaida) (white squares) with the location of the palaeontological site (black dot) over the raster of MAT values. b) Reconstruction of the landscape in Unit III from La Pedrera obtained by applying the Habitat Weighting method on the small mammal remains. OD: Open dry; OH: Open humid; Wo: Woodland; R: Rocky; Wa: Water.

\section{ACKNOWLEDGEMENTS}

This work has been possible thanks to the Sociedad Española de Paleontología who has funded this project. Also, the authors want to thank the reviewers Carmen Sesé and Juan Manuel López García for the corrections and the constructive comments.

\section{REFERENCES}

Agustí, J. 1986. Synthèse biostratigraphique du Plio Pleistocène de Guadix Baza (province de Granada, sud est de l'Espagne). Geobios, 19, 505-510; doi: 10.1016/ S0016-6995(86)80007-9.

Agustí, J., Santos-Cubedo, A., Furió, M., de Marfá, R., Blain, H.-A., Oms, O. \& Sevilla, P. 2011. The late Neogene-early Quaternary small vertebrate succession from the Almenara-Casablanca karst complex (Castellón, Eastern Spain): Chronologic and paleoclimatic context. Quaternay International, 243, 183-191; doi: 10.1016/j. quaint.2010.11.016.
Andrews, P. 1990. Owls, Caves and Fossils. University of Chicago Press.

Arrizabalaga Blanch, A., Torre Coromines, I., Catzeflis, F., Renaud, F. \& Santalla Quilles, F. 1999. Primera citació d'Apodemus flavicollis (Melchior, 1834) al Montseny. Determinació morfològica i genètica. III i IV Trobada d'Estudiosos del Montseny. Diputació de Barcelona, 193-195.

Ayarzagüena, J. \& López Martínez, N. 1976. Estudio filogenético y comparativo de Microtus cabrerae y Microtus brecciensis. Doñana, 3, 181-204.

Bateson, W. 1885. The later stages in the development of Balanoglossus kowalevskii, with a suggestion as to the affinities of the Enteropneusta. Quarterly Journal of Microscopical Science, 25, 81-122.

Bechstein, J.M. (ed.) 1800. Thomas Pennant's allgemeine Uebersicht der vierfüßigen Thiere. Aus dem Englischen übersetzt und mit Anmerkungen und Zusätzen versehen von Johann Matthäus Bechstein. Zweyter Band, i-xi, 323768, Taf. 35-54. Verlag des Industrie-Comptoir's, Weimar.

Blain, H.-A. 2009. Contribution de la paléoherpétofaune (Amphibia \& Squamata) à la connaissance de l'évolution du climat et du paysage du Pliocène supérieur au Plétstocène moyen d'Espagne. PhD. Thesis, Muséum 
National d'Histoire Naturelle de Paris, Institut de Paléontologie Humaine.

Blain, H.-A., Bailón, S. \& Cuenca-Bescós, G. 2008. The Early-Middle Pleistocene palaeoenvironmental change base on the squamate reptile and amphibian proxy at the Gran Dolina site, Atapuerca Spain, Palaeogeography, Palaeoclimatology, Palaeoecology, 261, 177-192; doi: 10.1016/j.palaeo.2008.01.015.

Blain, H.-A., Bailón, S., Cuenca-Bescós, G., Arsuaga, J.L., Bermúdez de Castro, J.M. \& Carbonell, E. 2009. Longterm climate record inferred from Early-Middle Pleistocene amphibian and squamate reptile assemblages at the Gran Dolina cave, Atapuerca, Spain. Journal of Human Evolution, 56, 55-65; doi: 10.1016/j.jhevol.2008.08.020.

Blain, H.-A., Lózano-Fernández, I., Agustí, J., Bailón, S., Menéndez, L.G., Espígares, P.O., Ros-Montoya, S., Jiménez, J.M.A, Toro-Moyano, I., Martínez-Navarro, B. \& Sala, R. 2016. Redefining upon the climatic background of the Early Pleistocene hominid settlement in Western Europe: Barranco León and Fuente Nueva-3 (Guadix-Baza Basin, SE Spain). Quaternary Science Reviews, 144, 132144; doi: 10.1016/j.quascirev.2016.05.020.

Blasius, J.H. 1853. Beschreibung zweier neuer deutscher Fledermausarten. Archiv für Naturgeschichte, 19, 35-57.

Blumenbach, J.F. 1779. Handbuch der Naturgeschichte. J.C. Dieterich, Göttingen.

Bond, G., Showers, W., Cheseby, M., Lotti, R., Almasi, P., Priore, P., Cullen, H., Hajdas, I. \& Bonani, G. 1997. A pervasive millennial-scale cycle in North Atlantic Holocene and glacial climates. Science, 278, 1257-1266; doi: 10.1126/sciencie278.5341.1257.

Borkhausen, M.B. 1797. Deutsche Fauna. 1, 80.

Bowdich, T.E. 1821. An Analysis of the Natural Classifications of Mammalia: for the Use of Students and Travellers. Printed by J. Smith, Paris.

Brandt, J.F. 1855. Beiträge Zurnähern Kenntniss der Säugethiere Russlands. Buchdruckerei der Kaiserlichen Akad. der Wissenschaften.

Brunet-Lecomte, P., Brochet, G., Chaline, J. \& Delibes, M. 1987. Morphologie dentaire comparée de Pitymys lusitanicus et $P$. duodecimcostatus (Arvicolidae, Rodentia) dans le nord-ouest de l'Espagne. Mammalia, 51, 145-158.

Butler, P.M. 1998. Fossil history of shrews in Africa. In: Evolution of Shrews, (eds. Woojcik, J.M. \& Wolsan, M.). Mammal Research Institute, Polish Academy of Science, Bialow-ieza, 121-132.

Cabrera, A. 1907. Three new Spanish Insectivores. Annals and magazine of Natural History, 20, 212-215; doi: 10.1080/00222930709487326.

Cacho, I., Grimalt, O.J., Pelejero, C., Canals, M., Sierro, F.J., Flores, J.A. \& Shackleton, N. 1999. DansgaardOeschger and Heinrich event imprints in Alboran Sea paleotemperatures. Paleooceanography, 14, 698-705; doi: 10.1029/1999PA900044.

Callou, C. 1997. Diagnose différentielle des principaux éléments squelettiques du lapin (genre Oryctolagus) et du lièvre (genre Lepus) en Europe occidentale. Fiches d'ostéologie animale pour l'archéologie, Série B, Mammifères, 8, 1-23.
Carmona, P., Fumanal, M.P., Juliá, R., Procynska, H., Solé A., Styansa, W. \& Viñals, M.J. 1993. Contexto geomorfológico y cronoestratigráfico de algunos paleosuelos valencianos. Cuaternario de España y Portugal, ITGE, 2, 533-543.

Chaline, J. 1972. Les Rongeurs du Pléistocène Moyen et Supérieur de France. (Systématique, Biostratigraphie, Paléoclimatologie). Ph.D. Thesis, C.N.R.S.

Chaline, J. 1988. Paleocronòmetres, paleotermòmetres i paleoindicadors dels entorns prehistòrics, els rosegdors irremplaçables. Cota zero, 4, 61-64.

Cucchi, T., Vigne, J.-D. \& Auffray, J.-C. 2005. First occurrence of the house mouse (Mus musculus domesticus, Schwarz and Schwarz, 1943) in the western Mediterranean: a zooarchaeological revision of subfossil occurrences. Biological Journal of the Linnean Society, 84, 429-445; doi: 10.1111/j.1095-8312.2005.00445.x.

Cuenca-Bescós, G., Rofes, J. \& García-Pimienta, J.C. 2005. Early Europeans and environmental change across the Early-Middle Pleistocene transition: small mammalian evidence from Trinchera Dolina cave, Atapuerca, Spain. In: Early-Middle Pleistocene Transitions: the Land-Ocean Evidence (eds. Head, M.J. \& Gibbard, P.L.). Geological Society of London, Special Publications, London, 247, 277-286.

Cuenca-Bescós, G., Strauss, L.G., González Morales, M.R. \& García Pimienta, J.C. 2009. The reconstruction of past environments through small mammals: from the Mousterian to the Bronze Age in El Mirón Cave (Cantabria, Spain). Journal of Archaeological Sciencie, 36, 647-955; doi: doi:10.1016/j.jas.2008.09.025.

Cuenca-Bescós, G., Rofes, J., López-García, J.M., Blain, H.A., De Marfà, J.R., Galindo-Pellicena, M.A., BennàsarSerra, M.L., Melero-Rubio, M., Arsuaga, J.L., Bermúdez de Castro, J.M. \& Carbonell, E. 2010. Biochronology of Spanish Quaternary small vertebrate faunas. Quaternary International, 212, 109-119; doi: 10.1016/j. quaint.2009.06.007.

Daams, R. 1981. The dental pattern of the dormice Dryomys, Myomimus, Microdyromys and Peridyromys. Utrecht micropaleontological bulletins, Special Publication, 3, 115.

De Marfá, R., Agustí, J. \& Cuenca-Bescós, G. 2006. Los lagomorfos del Plio-Pleistoceno europeo. State-of-the-art. Libro de resúmenes de las XXII Jornadas de la Sociedad Española de Paleontología, León, 112-114.

De Sélys-Longchamps, E. 1839. Etudes de Micromammalogie. Revue des Musaraignes, des Rats et des Campagnols, Sivie d'une Index Methodique des Mammiferes d'Europe. Librairie Encyclopedique de Roret, Paris.

Delany, M.J. 1976. The Ecology of Small Mammals. Edward Arnold, London.

Donard, E. 1982. Recherches sur les léporidés (Lagomorpha) Qaternaires (Pléistocène Moyen et Supérieur, Holocène). Ph.D. Thesis, Université de Bordeaux.

Estrela, M.J., Fumanal, P. \& Garay, P. 1993. Evolución geomorfológica de los valles Prebéticos nororientales. Cuaternario y Geomorfología, 7, 157-170.

Fejfar, O. \& Heinrich, W.-D. 1989. Muroid Rodent Biochronology of the Neogene and Quaternary in Europe. 
In: European Neogene Mammal Chronology (eds. Lindsay, E.H., Fahlbusch, V. \& Mein, P.). NATO ASI Series A, 180, 91-117.

Fejfar, O., Heinrich, W.-D. \& Lindsay, E.H. 1998. Updating the Neogene rodent biochronology in Europe. Mededelingen Nederlands Instituut voor Toegepaste Geowetenschappen TNO, 60, 533-554.

Fernández Peris, J., Guillem, P.M., Fumanal, Ma.P. \& Martínez Valle, R. 1994. Cova de Bolomor (Tavernes de la Valldigna, Valencia) primeros datos de una secuencia del Pleistoceno medio. SAGVNTVM, 27, 9-37.

Fischer von Waldheim, G. 1817. Adversaria zoologica. Mémoires de la Société impériale des naturalistes de Moscou, 5, 357-472.

Forsyth Major, C. 1905. Notes on European Species of the subgenus Pitymys. Annals and Magazine of Natural History, 7, XV, 503.

Fracasso, M.P.A., de Oliveira Salles, L. \& Perini, F.A. 2011. Upper molar morphology and relationships among higher taxa in bats. Journal of Mammalogy, 92, 421-432; doi: 10.1644/09-MAMM-A-415.1.

Furió, M. 2007. Los insectívoros (Soricomorpha, Erinaceomorpha, Mammalia) del Neógeno Superior del Levante Ibérico. Ph.D. Thesis, Universitat Autònoma de Barcelona (unpublished).

García, A., Soubrier, J., Muelas, A., Goy, J.L. \& Zazo, C. 1979. Mapa Geológico de Játiva, 795 (29-31), E. 1/50.000, $2^{\circ}$ serie, $1^{\circ}$ edición. IGME, Madrid.

Gauch, H.G. 1989. Multivariate Analysis in Community Ecology. Cambridge University Press, Cambridge, England.

Gerbe, Z. 1879. Diagnose d'un campagnol nouveau de France. Le naturaliste, 1, 51.

González Martín, J.A. \& Fidalgo, C. 2015. Las acumulaciones tobáceas: exigencias geoambientales y distribución espaciotemporal. In: Las Tobas en España. (eds. González, A. \& González, J.). Sociedad Española de Geomorfología. 315-355.

Gray, J.E. 1825. Outline of an attempt at the disposition of the Mammalia into tribes and families with a list of the genera apparently appertaining to each tribe. Annals of Philosophy, 10, 337-344.

Guillem, P.M. 1995. Bioestratigrafía de los micromamíferos (Rodentia, Mammalia) del Pleistoceno Medio, Superior y Holoceno del País Valenciano. Saguntum, 38, 11-18.

Guillem, P.M. 1996. Micromamíferos cuaternarios del País Valenciano: tafonomía, Bioestratigrafía y reconstrucción paleoambiental. Ph.D. Thesis, Universitat de València.

Guillem, P.M. 2009. Los micromamíferos (Rodentia, Insectívora y Chiroptera). In: Prehistoria, Arqueología y Antigüedad. Tomo II. Los Primeros Pobladores de la Costera: los Neandertales de la Cova Negra de Xàtiva (eds. Villaverde, V., Pérez Ballester, J. \& Ledo Coor, A.C.). Exc. Ajuntament de Xàtiva, Universitat de València, 85-11.

Heinrich, H. 1988. Origin and consequences of cycling ice rafting in the northeast Atlantic Ocean during the past 130,000 years. Quaternary Research, 29, 142-152; doi: 10.1016/0033-5894(88)90057-9.
Hernández-Fernández, M. \& Pelaéz-Campomanes, P. 2005. Quantitative palaeoclimatic inference based on terrestrial mammal faunas. Global Ecology and Biogeography, 14, 39-56; doi: 10.1111/j.1466-822X.2004.00125.x.

Hijmans, R.J., Cameron, S.E., Parra, J.L., Jones, P.G. \& Jarvis, A. 2005. Very high resolution interpolated climate surfaces for global land areas. International Journal of Climatology, 25, 1965-1978; doi: 10.1002/joc.1276.

Horáček, I., Maul, L.C., Smith, K.T., Barkai, R. \& Gopher, A. 2013. Bat remains (Mammalia, Chiroptera) from the Middle Pleistocene site of Qesem Cave, Israel, with the first Pleistocene record of fruit bats in the Mediterranean region. Palaeontologia Electronica, 16, 1-19.

Illiger, C. 1811. Prodromus Systematis Mammaliurn Etavium Additis Terminis Zoographicis Utriusque Classis. p. 301.

Jeannet, M. 2000. Gruta da Figueira Brava: les rongeurs. In: Últimos Neandertais em Portugal: Evidência, Odontológica e Outra (ed. Antunes, M.T.). Academia das Ciências de Lisboa, Lisboa, 179-243.

Kaup, J.J. 1829. Skizzirte Entwickelungs-Geschichte und Natürliches System der Europäischen Thierwelt. Leske, Darmstadt.

Kuhl, H. 1817. Die deutschen Fledermäuse. Hanau.

Lacépède, B.G.É. 1799. Tableau des divisions, sous-divisions, orders et genres des mammifères. pp. 1-20. In: Discours d'Ouverture et de Cloture du cours d'Histoire Naturelle: l'an VII de la République, et Tableaux Methodiques des Mammifères et des Oiseaux (ed. Lacépède, B.G.É.). Plassan, Paris.

Linnaeus, C. 1758. Systema Naturae per Regna Tria Naturae, Secundum Classis, Ordines, Genera, Species cum Characteribus, Differentiis, Synonymis, Locis. Tenth ed. Vol. 1. Laurentii Salvii, Stockholm, 824 pp.

Linnaeus, C. 1766. Systema Naturae per Regna Tria Naturae, Secundum Classis, Ordines, Genera, Species cum Characteribus, Differentiis, Synonymis, Locis. Twelfth ed. Vol. 1. Laurentii Salvii, Stockholm, 320 pp.

López-García, J.M. 2011. Los Micromamíferos del Pleistoceno Superior de la Península Ibérica. Evolución de la Diversidad Taxonómica y Cambios Paleoambientales y Paleoclimaticos. Saarbrucken. Editorial Academica Española, p. 1-364.

López-García, J.M., Blain, H.A., Cuenca Bescós, G. \& Arsuaga, J.L. 2008. Chronological, environmental, and climatic precisions on the Neanderthal site of the Cova del Gegant (Sitges, Barcelona, Spain). Journal of Human Evolution, 55, 1151-1155; doi: 10.1016/j. jhevol.2008.08.001.

López-García, J.M., Blain, H.A., Cuenca-Bescós, G., RuizZapata, M.B., Dorado-Valiño, M., Gil-García, M.J., Valdeolmillos, A., Ortega, A.I., Carretero, J.M., Arsuaga, J.L., Bermúdez de Castro, J.M. \& Carbonell, E. 2010. Palaeoenvironmental and palaeoclimatic reconstruction of the Latest Pleistocene of El Portalón Site, Sierra de Atapuerca, northwestern Spain. Palaeogeography Palaeoclimatology Palaeoecology, 292, 453-464; doi: 10.1016/j.palaeo.2010.04.006.

López-García, J.M., Blain, H.A., Cuenca-Bescós, G., Alonso, C., Alonso, S. \& Vaquero, M. 2011. Small 
vertebrates (Amphibia, Squamata, Mammalia) from the late Pleistocene-Holocene of the Valdavara-1 cave (Galicia, northwestern Spain). Geobios, 44, 253-269; doi:10.1016/j.geobios.2010.10.001.

López-García, J.M., Blain, H.A., Burjachs, F., Ballesteros, A., Allue, E., Cuevas-Ruiz, G.E., Rivals, F., Blasco, R., Morales, J.I., Rodríguez-Hidalgo, A., Carbonell, E., Serrat, E. \& Rosell, J. 2012. A multidisciplinary approach to reconstructing the south-western European Neanderthals: the contribution of Teixoneres cave (Moià, Barcelona). Quaternary Sciences Review, 43, 33-44; doi: 10.1016/j. quascirev.2012.04.008.

López-Martínez, N. 1980. Los micromamíferos (Rodentia, Insectivora, Lagomorpha y Chiroptera) del sitio de ocupación achelense de Aridos-1 (Arganda, Madrid). In: Ocupaciones Achelenses en el Valle del Jarama (eds. Santonja, M., López-Martínez, N. \& Pérez-González, A.). Publicaciones de la Excelentísima Diputación de la Provincia de Madrid, 161-202.

López-Martínez, N. \& Ruiz Bustos, A. 1977. Descubrimiento de dos yacimientos del Pleistoceno medio en el karst de la Sierra Alfaguara (Granada). Síntesis estratigráfica de este período en la región Bética. Estudios geológicos, 33, 255-265.

Maul, L.C. \& Markova, A.K. 2007. Similarity and regional differences in Quaternary arvicolid evolution in Central and Eastern Europe. Quaternary international, 160, 81-99; doi: 10.1016/j.quaint.2006.09.010.

Melchior, H.B. 1834. Den danske Stats og Norges Pattedyr. Gyldendal. Kobenhavn. 289 pp.

Marshall, S.J. 2009. Glaciations, Quaternary. In: Encyclopaedia of Paleoclimatology and Ancient Environments (ed. Gornitz, V.). Springer, New York, 389-393.

McCoy, E.D. \& Connor, E.F. 1980. Latitudinal gradients in the species diversity of North American mammals. Evolution, 34, 193-203; doi: 10.2307/2408328.

Michaux, J. \& Pasquier, L. 1974. Dynamique des populations de mulots (Rodentia, Apodemus) en Europe durant le Quaternaire. Premières données. Bulletin Société Géologique de France, 26, 431-439.

Miller, G.S. 1908. Eighteen new European Voles. Annals and Magazine of Natural History, 1, 100-107.

Milne-Edwards, H. 1874. Recherches pour servir a l'Histoire Naturelle des Mammifères Comprenant des Considérations sur la Classification de ces Animaux. 1-2. Masson, Paris.

Muirhead, L. 1819. Mazology. In: The Edinburgh Encyclopedia, 13, 393-486.

Nicolas, V., Martinez-Vargas, J. \& Hugot, J.P. 2016. Preliminary note: Talpa aquitania nov. sp. (Talpidae, Soricomorpha) a new mole species from southwest France and north Spain. Bulletin de l'Academie Veterinaire de France, 168, 329-334.

Niethammer, J. \& Krapp, F. (eds.) 1978. Handbuch der Säugetiere Europas. Akad lagsgesellschaft, Wuesbaden.

Palomo, L.J., Gisbert, J. \& Blanco, J.C. (eds.) 2007. Atlas y Libro Rojo de los Mamíferos Terrestres de España. Dirección General para la Biodiversidad-SECEMSECEMU, Madrid.
Paunesco, A.C. \& Abbassi, M. 2002. Les variations d'Eliomys (Myoxidae, Rodentia) durant le Quaternaire: Aperçu sur des populations du Sud de la France, de Ligurie et d'Espagne. Bulletin du Musée d'anthropologie préhistorique de Monaco, 42, 3-13.

Pulido, A. 1979. Contribución al conocimiento de la hidrogeología del Prebético nororiental (Provincias de Valencia y Alicante). Memorias Instituto Geológico Minero de España, Madrid, 95, p. 410.

Rabeder, G. 1981. Die Arvicoliden (Rodentia, Mammalia) aus dem Pliozän und dem älteren Pleistozän von Niederösterreich. Beiträge zur Paläontologie von Österreich, 8, 1-373.

Reumer, J.W.F., 1984. Rusician and early Pleistocene Soricidae (Insectívora, Mammalia) from Tegelen (The Netherlands) and Hungary. Scripta Geologica. 73, 1-173.

Rofes, J. \& Cuenca-Bescós, G. 2011. Evolutionary history and biogeography of the genus Crocidura (Mammalia, Soricidae) in Europe, with emphasis on Crocidura kornfeldi. Mammalian Biology-Zeitschrift für Sängetierkunde, 76, 64-78.

Rowe, J.S. 1956. Uses of underground plant species in forestry. Ecology, 37, 461-473.

Ruiz Bustos, A., Moyano, I.T., Suárez, E.M. \& Gallego, M.A. 1982. Procesos evolutivos durante el Cuaternario medio y superior en las poblaciones de pequeños mamíferos del sur de la Península Ibérica. Condiciones climáticas que implican e importancia bioestratigráfica. Cuadernos de Prehistoria y Arqueología de la Universidad de Granada, 7, 9-35.

Sánchez-Goñi, M.F. \& d'Errico, F. 2005. La historia de la vegetación y el clima del último ciclo climático (OIS5OIS1, 140.000-10.000 años BP) en la Península Ibérica y su posible impacto sobre los grupos paleolíticos. In: Neandertales Cantábricos, Estado de la Cuestión. Actas de la Reunión Científica. (coords. Montes Barquín, R. \& Lasheras, J.A.). Museo de Altamira, Ministerio de Cultura, Santander 20, 115-129.

Santonja, M., Pérez-González, A., Domínguez-Rodrigo, M., Panera, J., Rubio-Jara, S., Sesé, C., Soto, E., Arnold, L.J., Duval, M., Demuro, M., Ortiz, J.E., de Torres, T., Mercier, N., Barba, R. \& Yravedra, J. 2014. The Middle Paleolithic site of Cuesta de la Bajada (Teruel, Spain): a perspective on the Acheulean and Middle Paleolithic technocomplexes in Europe. Journal of Archaeological Science, 49, 556-571; doi: 10.1016/j.jas.2014.06.003.

Schreber, J.C.D.V. 1774. Die Säugethiere in Abbildungen nach der Natur mit Beschreibungen. Erster Theil. Der Mensch. Der Affe. Der Maki. Die Fledermaus. Walther, Erlangen.

Sesé, C. 2005. Aportación de los micromamíferos al conocimiento paleoambiental del Pleistoceno Superior en la Región Cantábrica: Nuevos datos y síntesis. In: Neandertales Cantábricos, Estado de la Cuestión. Actas de la Reunión Científica. (coords. Montes Barquín, R. \& Lasheras, J.A.). Museo de Altamira, Ministerio de Cultura, Santander 20 167-200.

Sesé, C. \& Sevilla, P. 1996. Los micromamíferos del Cuaternario peninsular español: cronoestratigrafía e 
implicaciones bioestratigráficas. Revista Española de Paleontología, $\mathrm{N}^{\circ}$ Extraordinario, 278-287.

Sevilla, P. 1988. Estudio paleontológico de los quirópteros del Cuaternario español. Paleontologia i Evolució, 22, 113-233.

Stoddart, D.M. (ed.) 1979. Ecology of Small Mammals. Springer, doi: 10.1007/978-94-009-5772-5.

Thomas, O. 1906. A new vole from Spain. Annals and Magazine of Natural History, 7, 576-577.

Tomes, R.F. 1857. Description of four undescribed species of bats. Proceedings of the Zoological Society, 25, 50-54.

Van Cleef-Roders, J.T. \& Van Den Hoek Ostende, L.W. 2001. Dental morphology of Talpa europaea and Talpa occidentalis (Mammalia: Insectivora) with a discussion of fossil Talpa in the Pleistocene of Europe. Zoologische Mededelingen, 75, 51-68.

Van der Meulen, A. 1973. Middle Pleistocene smaller mammals from the Monte Peglia (Orvieto, Italy), with special reference to the phylogeny of Microtus (Arvicolidae, Rodentia). Quaternaria, 17, 1-144.

Van der Weerd, A. 1976. Rodents faunas of the Mio-Pliocene sediments of the Teruel-Alfambra Region, Spain. Utrecht Micropaleontological Bulletins Special Publication, 2, 1-217.
Vázquez-Navarro, J.A., Vázquez, A. \& Carcavilla, L. 2014. Caracterización general y Distribución espacial. In: Las Tobas en España. (eds. González, A. \& González, J.). Sociedad Española de Geomorfología, 2, 101-314.

von Schrank, F.V.P. 1798. Fauna Boica. Durchgedachte Geschichte der in Baiern Einheimischen und Zahmen Thiere. Erster Band, Stein, Nürnberg.

Waddell, P.J., Okada, N. \& Hasegawa, M. 1999. Towards resolving the interordinal relationships of placental mammals. Systematic Biology, 48, 1-5.

Wagler, J.G. 1832. Isis: 275. In: Mammals Species of the World, a Taxonomical and Geographical Reference (eds. Wilson, D.E. \& Reeder, D.M.). Johns Hopkins University Press: Baltimore, 220-311.

Wagner, J.A. 1840. Beschreibung einiger neuer Nager. Abhandlungen mathematisch-physische Classe. Königliche Bayerische Akademie der Wissenschafen München, 3, 173-218.

Wilson, D.E. \& Reeder, D.M. (eds.) 2005. Mammal Species of the World: a Taxonomic and Geographic Reference. Johns Hopkins University Press, Baltimore.

Whittaker, R.H., 1948. A vegetation analysis of the Great Smoky Mountains. Ph.D. Thesis, University of Illinois, Urbana. 
